\section{Starvation and oxidative stress resistance in Drosophila are mediated through the eIF4E-binding protein, d4E-BP}

\author{
Gritta Tettweiler, ${ }^{1,2}$ Mathieu Miron, ${ }^{2,3}$ \\ Mark Jenkins, ${ }^{1}$ Nahum Sonenberg, ${ }^{2}$ and \\ Paul F. Lasko ${ }^{1,4}$
}

${ }^{1}$ Department of Biology, McGill University, Montréal, Québec H3A 1B1, Canada; ${ }^{2}$ Department of Biochemistry and McGill Cancer Center, McGill University, Montréal, Québec H3G 1Y6, Canada

eIF4E, the mRNA 5' cap-binding protein, is regulated by its binding protein (4E-BP), a downstream target of phosphatidylinositol-3-OH kinase $[\mathrm{PI}(3) \mathrm{K}]$ signaling. We show that Drosophila 4E-BP (d4E-BP) activity becomes critical for survival under dietary restriction and oxidative stress, and is linked to life span. The Drosophila forkhead transcription factor (dFOXO) activates $d 4 E-B P$ transcription. We show that ectopic expression of d4E-BP in $\mathrm{dFOXO}$-null flies restores oxidative stress resistance to control levels. Thus, d4E-BP is an important downstream effector of a dFOXO phenotype, and regulation of translation by eIF4E is vital during environmental stress.

Supplemental material is available at http://www.genesdev.org.

Received March 2, 2005; revised version accepted June 13, 2005.

A rapid response is a crucial early line of defense in preventing cellular death in situations of stress (Sonenberg et al. 2000). Translational regulation allows an organism to generate quick responses to environmental cues by controlling the expression of protein from existing cellular mRNAs (Johnstone and Lasko 2001). Translation initiation of most eukaryotic $\mathrm{mRNAs}$ requires binding of eIF4F, a protein complex made up of eIF4A, eIF4G, and eIF4E, to the 5' cap structure (Gingras et al. 1999). eIF4E activity is highly regulated both by $\mathrm{Mnk} 1 / \mathrm{Mnk} 2$-dependent phosphorylation (Waskiewicz et al. 1997) and by repressor proteins termed eIF4E-binding proteins (4EBPs), which compete with eIF4G for the same binding site on eIF4E (Haghighat et al. 1995; Mader and Sonenberg 1995). 4E-BPs themselves are negatively regulated by phosphorylation, and are downstream effectors of the PI3K/TOR pathway (Miron et al. 2001). Under nutritionally favorable conditions, the evolutionarily conserved TOR pathway is active and results in 4E-BP phosphorylation. This prevents 4E-BP binding to eIF4E, thus upregulating translation (Schmelzle and Hall 2000; Hay

[Keywords: Stress response; D. melanogaster; d4E-BP; dFOXO; translational control]

${ }^{3}$ Present address: McGill University and Genome Québec Innovation Centre, 740 Avenue Dr. Penfield, Montréal, Québec H3A 1A4, Canada. ${ }^{4}$ Corresponding author.

E-MAIL paul.lasko@mcgill.ca; FAX (514) 398-5069.

Article published online ahead of print. Article and publication date are at http://www.genesdev.org/cgi/doi/10.1101/gad.1311805. and Sonenberg 2004). Conversely, poor nutrition causes inhibition of the TOR pathway, such that unphosphorylated 4E-BP represses translation through eIF4E binding.

Activation of the PI3K pathway stimulates Akt activity. Akt directly phosphorylates the forkhead transcription factor $\mathrm{dFOXO}$, which is a transcriptional activator of d4E-BP in flies, resulting in reduced $d 4 E-B P$ transcription (Jünger et al. 2003; Puig et al. 2003). Akt also activates TOR through tuberous sclerosis complex 2 (TSC2), which functions as a GTPase-activating protein (GAP) for the GTPase protein Rheb that activates TOR (Hay and Sonenberg 2004). Thus, activation of the PI3K pathway in Drosophila represses both the expression of the $d 4 E-B P$ gene and the activity of d4E-BP protein.

Here we investigated whether d4E-BP is essential under starvation and oxidative stress conditions, because $\mathrm{dFOXO}$ activates the transcription of $d 4 E-B P$ and $d 4 E-B P$ mRNA levels increase upon starvation (Zinke et al. 2002). We also provide evidence that d4E-BP activity is linked to life span, as overexpression of $\mathrm{dFOXO}$ is linked to increased longevity (Giannakou et al. 2004; Hwangbo et al. 2004). We present data that support both connections and indicate that $\mathrm{d} 4 \mathrm{E}-\mathrm{BP}$ is the critical effector of the dFOXO-induced stress-sensitive phenotype.

\section{Results and Discussion}

To investigate whether 4E-BP activity influences life span in Drosophila melanogaster, we determined the median life span of $d 4 E-B P^{\text {null }}$ flies in comparison to revertant control flies that were produced by a precise excision of the $P\{1 a c W\}$ insertion of Thor $^{1}$ (which disrupts the gene encoding d4E-BP) but which otherwise have the identical genetic background (Rodriguez et al. 1996; Bernal and Kimbrell 2000; Bernal et al. 2004; and see Supplementary Fig. S1 for details of the strain construction). These will subsequently be referred to as revertant flies. A null mutation in $d 4 E-B P$ caused a significant decrease in longevity (Fig. 1). The median life span of mutant males was $19.8 \mathrm{~d}, \sim 25 \%$ shorter than that of control males (Fig. 1A, median life span of $26.6 \mathrm{~d}$ ). The life span of females was longer than for males (Fig. 1B), but a comparable relative effect of the null mutation in $d 4 E-B P$ on life span was observed in both sexes. These results show that $\mathrm{d} 4 \mathrm{E}-\mathrm{BP}$, a target of the conserved PI3K/ TOR signaling pathway that has been strongly implicated in longevity, has a significant impact itself on life span.

In Drosophila larvae, protein-rich nutrition is critical for survival, while adults can survive up to $3 \mathrm{wk}$ without protein. Strikingly, we observed that larval d4E-BP protein levels rise rapidly during nutritional stress (Fig. 2). A dramatic increase of $\sim 10$-fold is observed after $8 \mathrm{~h}$ of starvation. To determine whether this increase in d4E$\mathrm{BP}$ level is important for survival following starvation, we collected eggs from Oregon- $\mathrm{R}, d 4 E-B P^{n u i l}$, and revertant flies, transferred them to starvation medium, and scored mortality at 12 -h intervals. Drosophila $4 E-B P^{\text {null }}$ larvae die substantially faster than their control counterparts under starvation (Fig. 3, median life span of $20.8 \mathrm{~h}$ for starved $d 4 E-B P^{\text {null }}$ larvae, $26.4 \mathrm{~h}$ for revertant, and $26.2 \mathrm{~h}$ for Oregon-R larvae). To examine whether this effect can be overcome by induced expression of a $d 4 E$ $B P(w t)$ transgene in a $d 4 E-B P^{n u l l}$ background, we used the UAS-GAL4 system (Brand and Perrimon 1993) with 

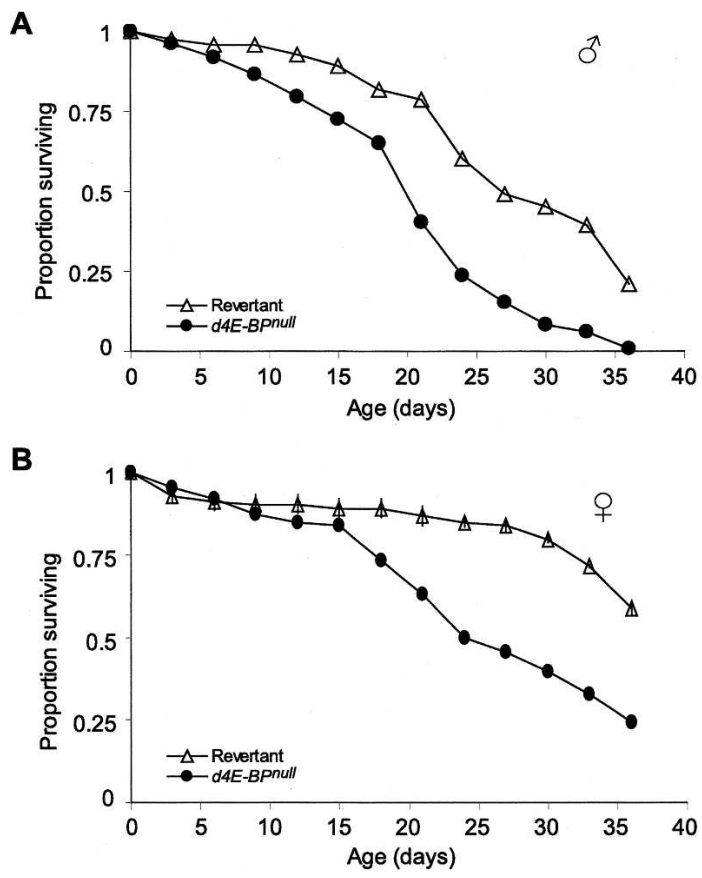

Figure 1. Life span of $D$. melanogaster is affected by the eIF4E inhibitory protein, 4E-BP. (A) The median life span of $d 4 E-B P^{\text {null }}$ males $(n=97)$ is $\sim 25 \%$ reduced compared with revertant males $(n=157) .(-\bullet) d 4 E-B P^{\text {rull }}$ flies; $(-\triangle-)$ revertant control. Statistical comparison (log-rank test): revertant control vs. $d 4 E-B P^{\text {null }}$ $p<0.0001$. (B) A null mutation in $d 4 E-B P$ has a comparable effect on the life span of female animals. Statistical comparison (log-rank test): revertant control $(n=165)$ vs. $d 4 E$ - $B P^{\text {null }}(n=86), p<0.0001$.

the heat-shock inducible $H s p 70$ promoter. Induction of $\mathrm{d} 4 \mathrm{E}-\mathrm{BP}$ expression in this manner fully rescues the increased sensitivity of $d 4 E-B P^{\text {null }}$ larvae to starvation (Fig. 3, median life span of $27 \mathrm{~h}$ ). Importantly, transgenic flies expressing a mutant version of d4E-BP [d4E$\mathrm{BP}(\mathrm{Y} 54 \mathrm{~A}, \mathrm{M} 59 \mathrm{~A})]$ that does not bind to eIF4E (Miron et al. 2001) were susceptible to starvation similar to the $d 4 E-B P^{n u l l}$ animals (Fig. 3, median life-span $22.6 \mathrm{~h}$ ). While the $d 4 E-B P(Y 54 A, M 59 A)$ larvae resisted nutritional stress somewhat better in the first $12 \mathrm{~h}$, after $36 \mathrm{~h}$ of complete starvation their survival was as poor as that of $d 4 E-B P^{n u 1 l}$ larvae (survival rates of $8.5 \%$ and $9.6 \%$, respectively) and far lower than that of control animals, or animals expressing d4E-BP from a transgene [survival rates of $26.8 \%$ for revertant larvae, $27.6 \%$ for Oregon-R larvae, and $30.3 \%$ for transgenic $d 4 E-B P(w t)$ larvae]. These results demonstrate clearly that the protective role of d4E-BP during starvation requires binding to eIF4E.

$\mathrm{dFOXO}$ is a transcriptional activator of $d 4 E-B P$ (Jünger et al. 2003; Puig et al. 2003; Wang et al. 2005). dFOXO loss-of-function mutants exhibit increased sensitivity to

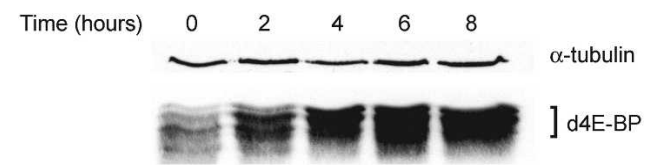

Figure 2. Time course of increasing expression of d4E-BP in response to nutrient stress: 40-h-old larvae of revertant animals were subjected to complete starvation. Identical amounts of total protein (30 $\mu \mathrm{g})$ were analyzed by Western blot with 1868 antibody to d4E-BP. Loading control, $\alpha$-tubulin.

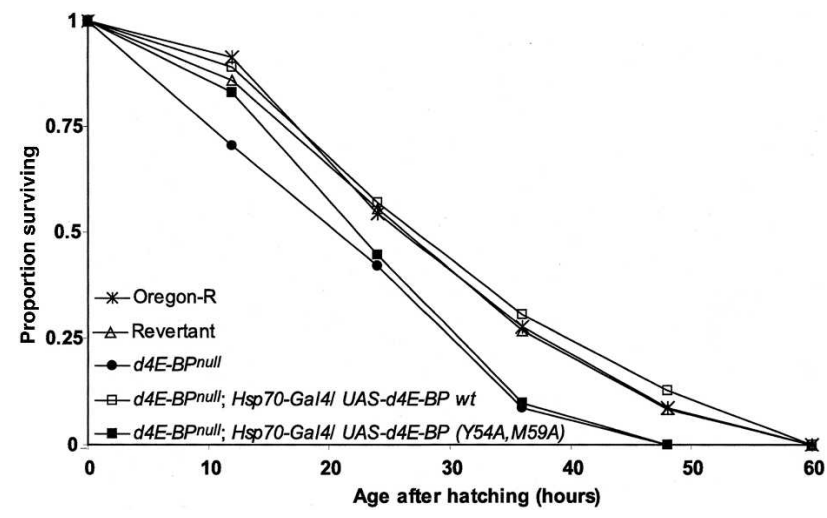

Figure 3. d4E-BP binding to eIF4E is required to rescue nutritional stress resistance. Eggs were subjected to complete starvation, and surviving larvae were counted every $12 \mathrm{~h} . d 4 E-B P^{\text {null }}$ larvae $(-\bullet-)$ died significantly faster than revertant control larvae $(-\triangle-)$. This effect can be rescued by overexpression of d4E-BP ( - - -), but not by overexpression of d4E-BP(Y54A,M59A) (- - ) , a mutant form that cannot bind to eIF4E. Statistical comparison (log-rank test): revertant control $(n=157)$ vs. $d 4 E-B P^{n u l l}(n=200)$, and revertant control vs. d4E-BP $P^{\text {null }}$; Hsp70-GAL4/UAS-d4E-BP(Y54A,M59A) $(n=270)$, $p<0.0001$. Revertant control vs. d4E-BP $P^{\text {null }}$; Hsp 70-Gal4/UAS-d4E$B P(w t)(n=102), p=0.345$ (not significant). Each data point represents the aggregate of results from three independent experiments.

oxidative stress (Jünger et al. 2003). Since $d 4 E-B P$ is a downstream target of $\mathrm{dFOXO}$, we compared the sensitivity of $E P$-dFOXO $O^{21} / E P-d F O X O^{25}$ flies and $d 4 E-B P^{n u l l}$ flies to oxidative stress. $E P-d F O X O^{21} / E P-d F O X O^{25}$ is null for $d F O X O$ function (Jünger et al. 2003) and is subsequently referred to here as $d F O X O$-null for brevity. Indeed, on medium containing $5 \%$ hydrogen peroxide, we observed a reduced median life span of $d F O X O$-null and $d 4 E-B P^{\text {null }}$ flies (Fig. 4, median life spans of $34.6 \mathrm{~h}$ and $23.2 \mathrm{~h}$, respectively). The survival rate at $60 \mathrm{~h}$ after exposure to oxidative stress was $0 \%$ for $d 4 E-B P^{\text {null }}$ animals, and only $2 \%$ for $d F O X O$-null flies, compared with $66.1 \%$ for wild-type controls. Thus, an intriguing possibility is that $\mathrm{d} 4 \mathrm{E}-\mathrm{BP}$ acts as the downstream mediator of the $d F O X O$-null phenotype. As is the case for d4E-BPmediated protection against starvation, this effect can be rescued by ectopic expression of d4E-BP (Fig. 4, median life span of $55.4 \mathrm{~h}$ ). The resistance to oxidative stress was also dependent on eIF4E binding, since d4E-BP(Y54A, M59A) was unable to rescue stress sensitivity (Fig. 4, median life span of $24.1 \mathrm{~h}, 0.4 \%$ survival rate at $60 \mathrm{~h}$ ). The heat shock itself did not significantly affect life span (see Supplementary Fig. S3). To examine whether reduced levels of d4E-BP protein could account for the oxidative stress sensitivity of $d F O X O$-null mutants, we ectopically expressed d4E-BP in a dFOXO-independent manner in these animals. Remarkably, ectopic expression of d4E-BP completely rescued the sensitivity of dFOXO-null animals to oxidative stress (Fig. 4, median life span of $56.8 \mathrm{~h}, 39.7 \%$ survival rate after $60 \mathrm{~h}$ exposure to $5 \% \mathrm{H}_{2} \mathrm{O}_{2}$ ). Taken together, these results demonstrate that $\mathrm{d} 4 \mathrm{E}-\mathrm{BP}$ is a critical downstream mediator of dFOXO in oxidative stress resistance.

Normal growth and development are suspended during stress in order to concentrate resources on an appropriate stress response, and repressing translation does, in fact, slow growth (Grolleau et al. 2002; Patel et al. 2002). We have shown that d4E-BP is strongly up-regulated during starvation, and its absence leads to compromised sur- 


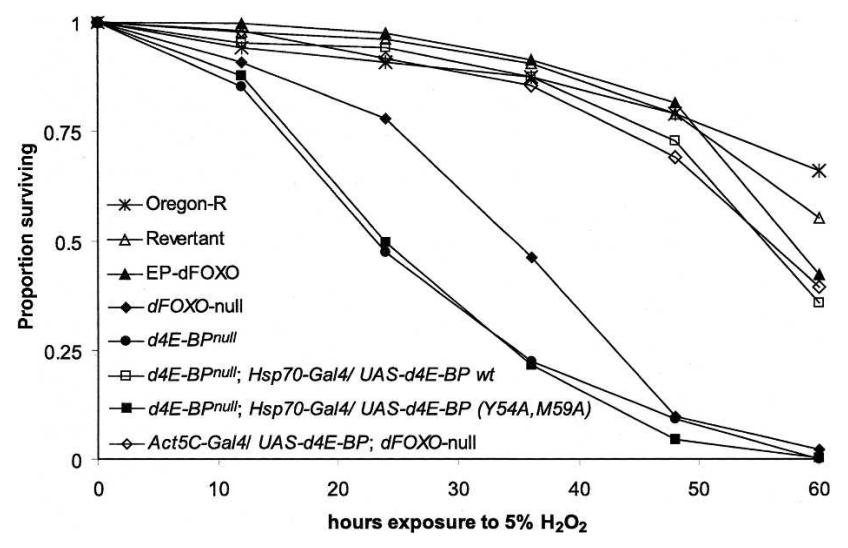

Figure 4. d4E-BP mediates the oxidative stress resistance of dFOXO. Flies were exposed to $5 \% \mathrm{H}_{2} \mathrm{O}_{2}$, and survival was determined at 12 -h intervals. Oregon-R flies were used as control. For $d 4 E-B P^{\text {null }}(-\bullet-)$ and $d F O X O$-null flies $(-\downarrow)$, mortality at $60 \mathrm{~h}$ was $100 \%$ and $98 \%$, respectively, compared with $33.9 \%$ for Oregon-R (- $\mathbf{\Delta - 1}$. Ectopic expression of d4E-BP in a d4E-BP $P^{\text {null }}$ background rescued this effect $(-\square-, 64 \%$ mortality at $60 \mathrm{~h})$, but not ectopic expression of d4E-BP(Y54A,M59A) (- - $99.6 \%$ mortality at $60 \mathrm{~h}$ ). Overexpression of d4E-BP in a $d F O X O$-null background $(-\diamond-, 60.3 \%$ mortality after $60 \mathrm{~h})$ rescued the stress-sensitive phenotype of $d F O X O$-null flies. Survival data from three to six independent experiments were combined to clarify statistical analysis. Statistical comparison (log-rank test): Oregon-R $(n=118)$ vs. $d F O X O-n u l l ~(n=224)$, Oregon- $R$ vs. $d 4 E-B P^{\text {null }}(n=120)$, Oregon- $R$ vs. $d 4 E-B P^{\text {null }} ; H$ Hsp 70-Gal4/UAS-d4E-BP(wt) $(n=150)$, Oregon-R vs. $d 4 E-B P^{\text {null }} ; \quad H s p 70 G A L 4 / U A S-d 4 E-B P(Y 54 A, M 59 A)(n=274)$, all $p<0.0001$. Oregon-R vs. Act5CGAL4/UAS-d4E-BP(wt);dFOXOnull $(n=156), p=0.109$ (not significant). Supplementary Figure S2 provides evidence that ectopic expression of $d 4 E-B P$ can also rescue starvation sensitivity of $d F O X O$-null larvae.

vival under outright starvation. The importance of d4E-BP in nutrient stress response is underscored by the fact that it is one of a small set of $\sim 14$ genes whose expression is up-regulated as a consequence of starvation (Zinke et al. 2002; this study). Our data support the current models to explain how oxidative stress activates transcription of $d 4 E-B P$. Oxidative stress promotes dephosphorylation of dFOXO, which causes its transport into the nucleus and activation of $d 4 E$ $B P$ transcription (Jünger et al. 2003). Amino acid starvation activates the dTOR pathway in the larval fat body. This triggers a starvation signal that suppresses the Inr/PI3K pathway in peripheral tissues (Colombani et al. 2003). Suppression of this pathway results in inactivation of $\mathrm{dAkt}$, which in turn can no longer phosphorylate and inactivate dFOXO, causing enhanced transcription of $d 4 E$ $B P$ (Fig. 5).

Since the function of $\mathrm{d} 4 \mathrm{E}-\mathrm{BP}$ in stress resistance requires its eIF4E-binding activity, we propose that it involves repression of cap-dependent translation, concomitant with the stimulation of cap-independent translation. The up-regulation of d4E-BP could result in preferential translation of mRNAs, which translate in a cap-independent manner, via an internal ribosome entry site (IRES) element. Such stimulation has been documented under stress conditions including irradiation, hypoxia, and nutrient deprivation (Holcik et al. 2000). It is also possible that d4E-BP exerts its effects by inhibiting the translation of key mRNA targets as was documented in mammals /Gingras et al. 1999). Mammalian eIF4E preferentially stimulates the translation of mRNAs with a high degree of secondary structure in their mRNA 5'UTRs (Gingras et al. 1999). These mRNAs, which are inefficiently translated, mostly encode proteins that play important roles in cell growth and proliferation (van der Velden and Thomas 1999).

Recent studies show that overexpression of dFOXO in adult fat bodies can extend the Drosophila life span (Giannakou et al. 2004; Hwangbo et al. 2004). Further, overexpression of dTSC1, dTSC2, or dominant-negative forms of dTOR or dS6K all extend the life span of Drosophila (Kapahi et al. 2004). Interestingly, TOR also regulates life span in Caenorhabditis elegans (Jia et al. 2004). Our data support a role for d4E-BP in mediating life span, most likely as an effector of dFOXO. Taken together, our results add to the increasing body of evidence supporting a key role for 4E-BP-mediated regulation of eIF4E in controlling cell growth, proliferation, and survival (Miron et al. 2001; Fingar et al. 2002; Li et al. 2002; Avdulov et al. 2004; Bjornsti and Houghton 2004).

\section{Materials and methods}

\section{Drosophila strains}

$d 4 E-B P^{\text {null }}$ and revertant control flies are as described in Supplementary Figure S1. dFOXO-null alleles $d F O X O^{21}$ and $d F O X O^{25}$ are as described (Jünger et al. 2003).

\section{Life span assay}

For life span assays, male and female flies from a 24-h eclosion period were collected separately, and maintained at $25^{\circ} \mathrm{C}$ on standard cornmeal/ agar medium in cages. Every 3 d, flies were transferred to fresh medium,

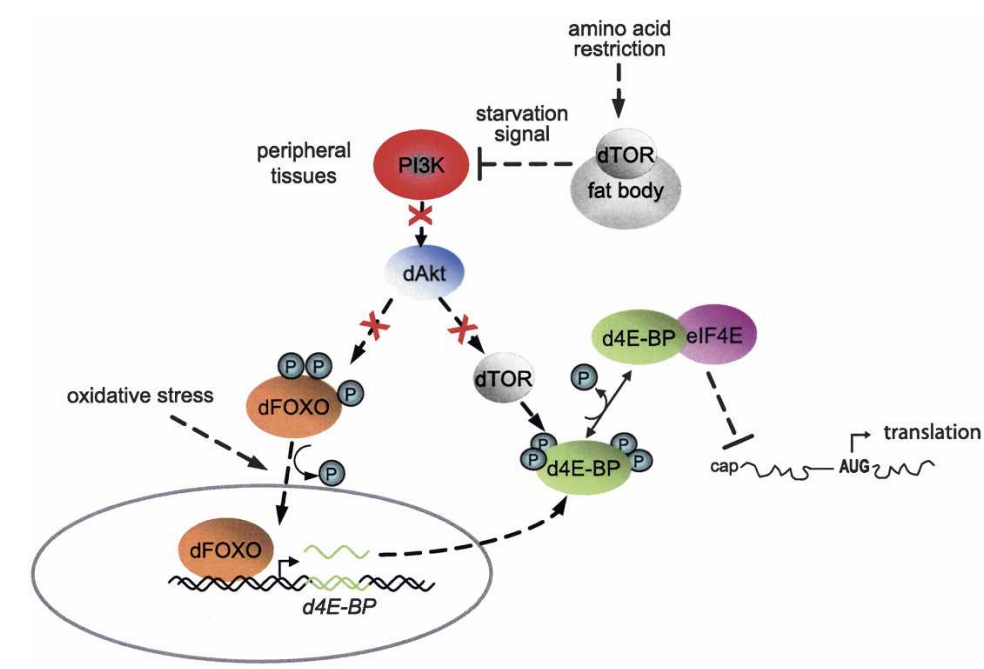

Figure 5. d4E-BP is an important downstream effector of the dFOXO phenotype. Under oxidative stress, dFOXO becomes dephosphorylated, and enters the nucleus to activate $d 4 E-B P$ transcription. Amino acid starvation inhibits the dTOR pathway in the larval fat body, which results in suppression of the Inr/ PI3K pathway in peripheral tissues. This affects d4E-BP regulation in two ways. First, suppression of Inr/PI3K signaling leads to inactivation of dAkt. Consequently, dAkt cannot phosphorylate dFOXO, resulting in enhanced transport of $\mathrm{dFOXO}$ to the nucleus and transcriptional activation of $d 4 E-B P$. Also, the d4EBP kinase dTOR is a downstream target of the PI3K pathway. Under starvation, dTOR is inactive, such that d4E-BP does not become phosphorylated, and can interact with eIF4E. Thus, amino acid starvation increases both the protein level and activity of d4E-BP, which results in repression of cap-dependent translation. 
and the survivorship was determined. For analysis, the median life span was calculated as $50 \%$ survival.

\section{Stress treatments}

Eggs were collected from females for $2 \mathrm{~h}$, separated from media, rinsed with $70 \%$ ethanol for $10 \mathrm{sec}$, rinsed with distilled $\mathrm{H}_{2} \mathrm{O}$, and placed individually into 200- $\mu \mathrm{L}$ PCR tubes (Abgene). Tubes contained $100 \mu \mathrm{L}$ of starvation media, with single air holes poked in the lids. Survivors were counted every $12 \mathrm{~h}$. Starvation medium: $2 \%$ agar in $1 \times \mathrm{PBS}$ at $\mathrm{pH}$ 7.4. The survival rate under $5 \% \mathrm{H}_{2} \mathrm{O}_{2}$ was measured as described (Jünger et al. 2003), with mortality counts every $12 \mathrm{~h}$. To induce expression of UAS$d 4 E-B P(w t)$ and $U A S-d 4 E-B P(Y 54 A, M 59 A)$ respectively, flies were heatshocked twice per day for $40 \mathrm{~min}$ at $37^{\circ} \mathrm{C}$. Each survival curve represents the sum of data from three to six independent experiments.

Antibodies and Western blotting analysis

Anti-d4E-BP antibody 1868 has been previously described (Miron et al. 2001). Polypeptides were resolved on $15 \%$ SDS-polyacrylamide gels and transferred to $0.22-\mu \mathrm{m}$ nitrocellulose membranes. Membranes were blocked with $2 \%$ nonfat dry milk in PBS containing $0.5 \%$ Tween-20 (PBST; all subsequent incubations were performed in the same solution) for $2 \mathrm{~h}$ and incubated for $2 \mathrm{~h}$ with primary antibody 1868 (1:2000) or anti- $\alpha$-tubulin (clone DM1A; Sigma; 1:10000). Incubation with secondary antibody was performed with peroxidase-coupled donkey anti-rabbit Ig or anti-mouse Ig (Amersham; 1:5000) followed by ECL (Amersham).

\section{Acknowledgments}

We thank Deborah Kimbrell, Martin Jünger, and Ernst Hafen for fly stocks. This work was supported by an operating grant from the Canadian Institute of Health Research (CIHR) to P.L. and N.S. N.S. is a CIHR Distinguished Scientist and a Howard Hughes Medical Institute (HHMI) International Scholar.

\section{References}

Avdulov, S., Li, S., Michalek, V., Burrichter, D., Peterson, M., Perlman, D.M., Manivel, J.C., Sonenberg, N., Yee, D., Bitterman, P.B., et al. 2004. Activation of translation complex eIF4F is essential for the genesis and maintenance of the malignant phenotype in human mammary epithelial cells. Cancer Cell 5: 553-563.

Bernal, A. and Kimbrell, D.A. 2000. Drosophila Thor participates in host immune defense and connects a translational regulator with innate immunity. Proc. Natl. Acad. Sci. 97: 6019-6024.

Bernal, A., Schoenfeld, R., Kleinhesselink, K., and Kimbrell, D. 2004. Loss of Thor, the single 4E-BP gene of Drosophila, does not result in lethality. Drosoph. Inf. Serv. 87: 81-84.

Bjornsti, M.A. and Houghton, P.J. 2004. Lost in translation: Dysregulation of cap-dependent translation and cancer. Cancer Cell 5: 519-523.

Brand, A.H. and Perrimon, N. 1993. Targeted gene expression as a means of altering cell fates and generating dominant phenotypes. Development 118: 401-415.

Colombani, J., Raisin, S., Pantalacci, S., Radimerski, T., Montagne, J., and Léopold, P. 2003. A nutrient sensor mechanism controls Drosophila growth. Cell 114: 739-749.

Fingar, D.C., Salama, S., Tsou, C., Harlow, E., and Blenis, J. 2002. Mammalian cell size is controlled by mTOR and its downstream targets S6K1 and 4EBP1/eIF4E. Genes \& Dev. 16: 1472-1487.

Giannakou, M.E., Goss, M., Junger, M.A., Hafen, E., Leevers, S.J., and Partridge, L. 2004. Long-lived Drosophila with overexpressed dFOXO in adult fat body. Science 305: 361.

Gingras, A.C., Raught, B., and Sonenberg, N. 1999. eIF4 initiation factors: Effectors of mRNA recruitment to ribosomes and regulators of translation. Annu. Rev. BioChem. 68: 913-963.

Grolleau, A., Bowman, J., Pradet-Balade, B., Puravs, E., Hanash, S., Garcia-Sanz, J.A., and Beretta, L. 2002. Global and specific translational control by rapamycin in $\mathrm{T}$ cells uncovered by microarrays and proteomics. J. Biol. Chem. 277: 22175-22184.

Haghighat, A., Mader, S., Pause, A., and Sonenberg, N. 1995. Repression of cap-dependent translation by 4E-binding protein 1: Competition with p220 for binding to eukaryotic initiation factor-4E. EMBO J. 14: 5701-5709.

Hay, N. and Sonenberg, N. 2004. Upstream and downstream of mTOR.
Genes \& Dev. 18: 1926-1945.

Holcik, M., Sonenberg, N., and Korneluk, R.G. 2000. Internal ribosome initiation of translation and the control of cell death. Trends Genet. 16: 469-473.

Hwangbo, D.S., Gersham, B., Tu, M.P., Palmer, M., and Tatar, M. 2004. Drosophila dFOXO controls lifespan and regulates insulin signalling in brain and fat body. Nature 429: 562-566.

Jia, K., Chen, D., and Riddle, D.L. 2004. The TOR pathway interacts with the insulin signaling pathway to regulate C. elegans larval development, metabolism and life span. Development 131: 3897-3906.

Johnstone, O. and Lasko, P. 2001. Translational regulation and RNA localization in Drosophila oocytes and embryos. Annu. Rev. Genet. 35: 365-406.

Jünger, M.A., Rintelen, F., Stocker, H., Wasserman, J.D., Vegh, M., Radimerski, T., Greenberg, M.E., and Hafen, E. 2003. The Drosophila Forkhead transcription factor FOXO mediates the reduction in cell number associated with reduced insulin signaling. J. Biol. 2: 20.

Kapahi, P., Zid, B.M., Harper, T., Koslover, D., Sapin, V., and Benzer, S. 2004. Regulation of lifespan in Drosophila by modulation of genes in the TOR signaling pathway. Curr. Biol. 14: 885-890.

Li, S., Sonenberg, N., Gingras, A.C., Peterson, M., Avdulov, S., Polunovsky, V.A., and Bitterman, P.B. 2002. Translational control of cell fate: Availability of phosphorylation sites on translational repressor 4E-BP1 governs its proapoptotic potency. Mol. Cell Biol. 22: 2853 2861.

Mader, S. and Sonenberg, N. 1995. Cap binding complexes and cellular growth control. Biochimie 77: 40-44.

Miron, M., Verdu, J., Lachance, P.E., Birnbaum, M.J., Lasko, P.F., and Sonenberg, N. 2001. The translational inhibitor 4E-BP is an effector of $\mathrm{PI}(3) \mathrm{K} /$ Akt signalling and cell growth in Drosophila. Nat. Cell Biol. 3: 596-601.

Patel, J., McLeod, L.E., Vries, R.G., Flynn, A., Wang, X., and Proud, C.G. 2002. Cellular stresses profoundly inhibit protein synthesis and modulate the states of phosphorylation of multiple translation factors. Eur. J. Biochem. 269: 3076-3085.

Puig, O., Marr, M.T., Ruhf, M.L., and Tjian, R. 2003. Control of cell number by Drosophila FOXO: Downstream and feedback regulation of the insulin receptor pathway. Genes \& Dev. 17: 2006-2020.

Rodriguez, A., Zhou, Z., Tang, M.L., Meller, S., Chen, J., Bellen, H., and Kimbrell, D.A. 1996. Identification of immune system and response genes, and novel mutations causing melanotic tumor formation in Drosophila melanogaster. Genetics 143: 929-940.

Schmelzle, T. and Hall, M.N. 2000. TOR, a central controller of cell growth. Cell 103: 253-262.

Sonenberg, N., Hershey, J.W.B., and Mathews, M. 2000. Translational control of gene expression. Cold Spring Harbor Laboratory Press, Cold Spring Harbor, NY.

van der Velden, A.W. and Thomas, A.A. 1999. The role of the 5' untranslated region of an mRNA in translation regulation during development. Int. J. Biochem. Cell Biol. 31: 87-106.

Wang, M.C., Bohmann, D., and Jasper, H. 2005. JNK extends life span and limits growth by antagonizing cellular and organism-wide responses to insulin signaling. Cell 121: 115-125.

Waskiewicz, A.J., Flynn, A., Proud, C.G., and Cooper, J.A. 1997. Mitogenactivated protein kinases activate the serine/threonine kinases Mnk1 and Mnk2. EMBO J. 16: 1909-1920.

Zinke, I., Schutz, C.S., Katzenberger, J.D., Bauer, M., and Pankratz, M.J. 2002. Nutrient control of gene expression in Drosophila: Microarray analysis of starvation and sugar-dependent response. EMBO I. 21: 6162-6173. 


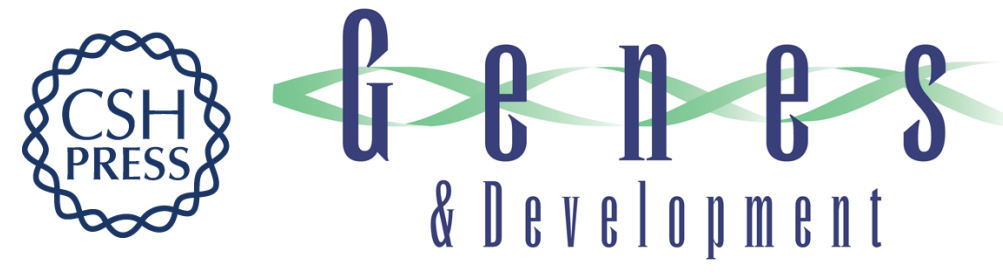

\section{Starvation and oxidative stress resistance in Drosophila are mediated through the elF4E-binding protein, d4E-BP}

Gritta Tettweiler, Mathieu Miron, Mark Jenkins, et al.

Genes Dev. 2005, 19:

Access the most recent version at doi:10.1101/gad.1311805

Supplemental
Material $\quad$ http://genesdev.cshlp.org/content/suppl/2005/07/29/gad.1311805.DC1

References This article cites 29 articles, 12 of which can be accessed free at:

http://genesdev.cshlp.org/content/19/16/1840.full.html\#ref-list-1

License

Email Alerting Receive free email alerts when new articles cite this article - sign up in the box at the top

Service right corner of the article or click here.

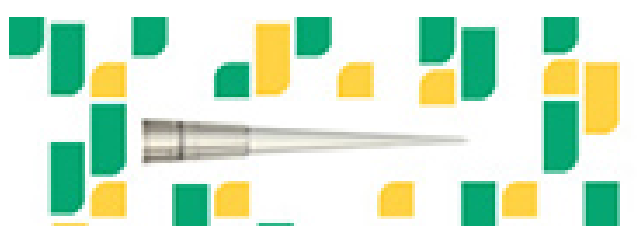

Focused on your science. 